\title{
ANALYSIS OF THE EFFECT OF CAPITAL ADEQUACY RATIO, NON PERFORMING FINANCING, AND FINANCING TO DEPOSIT RATIO ON PROFITABILITY: A CASE STUDY ON ISLAMIC COMMERCIAL BANKS IN INDONESIA
}

\author{
Ema Muawanah \\ Faculty of Economics and Business, Universitas Muhamadiyah Surakarta, Indonesia \\ emamuawanah17@gmail.com \\ Imronudin \\ Faculty of Economics and Business, Universitas Muhamadiyah Surakarta, Indonesia \\ imronudin@ums.ac.id
}

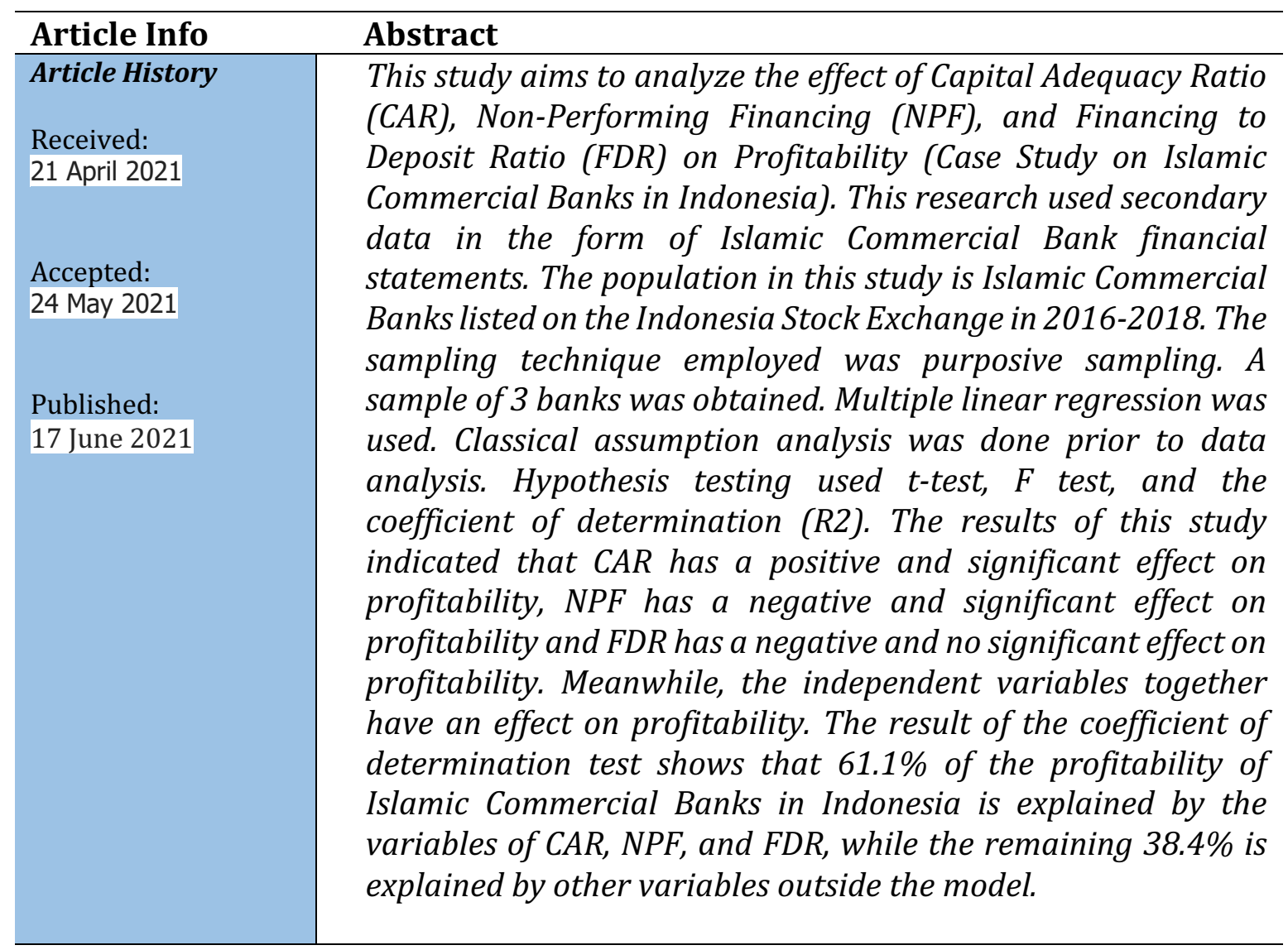

Keywords: Capital Adequacy Ratio (CAR), Non-Performing

Financing (NPF) dan Financing to Deposit Ratio (FDR)

\section{INTRODUCTION}

Islamic banks carry out their operations by collecting funds from the public and channel them back to customers through financing. Financing based on shariah principles according to the Law of the Republic of Indonesia No. 10 of 1988 article 1 paragraph 13 are rules of agreement 
based on Islamic Law between Bank and other party for depositing fund and/or financing business activities, or other activities which is stated as in accordance to Syariah Principles, i.e. financing based on profit sharing principle (mudharabah), financing based on equity participation (musharakab), sales of goods with profit principle (murabahab), or financing of capital goods based on pure lease without option (ijarah) or with an option of ownership transfer of goods leased from Bank to the other party (ijarah wa iqtina). Islamic banks do not use interest as a tool to earn income or charge interest on the use of funds and loans because interest is a riba, which is forbidden (Masood \& Ashraf, 2012). The characteristics of the Islamic banking system are operating based on the principle of profit-sharing, providing an alternative mutually beneficial banking system for the community and banks as well as highlighting aspects of fairness in transactions, ethical investments, values of togetherness and brotherhood in production and avoiding speculative activities in financial transactions (Ali et al., 2011). In Indonesia, where the majority of the population is Muslim, a sharia-based financial system is considered to be able to accommodate the needs of its people. The existence of Islamic banks is motivated by the awareness of Muslims who want to adhere to religious guidance. Besides, Muslims need interest-free banking and the financing of real business.

Islamic banks were initially developed as a response from a group of economists and Muslim banking practitioners in accommodating the pressures given by various parties who wanted financial transaction services with moral values and sharia principles in Islam. Philosophically, Islamic banks are banks whose activation leaves the riba. Thus, avoiding interest which is considered riba is one of the challenges. Therefore, an interest-free banking mechanism (Islamic bank) was established. Islamic banking was founded on both philosophical and practical grounds. Philosophically, it is due to the prohibition of riba in financial and non-financial transactions. Practically, because the interest-based or conventional banking system suffers weaknesses (Yuliarti, 2014).

Islamic banks have been officially introduced to the public since 1992 with the enactment of Law no. 7 of 1992 concerning banking. This law, which was interpreted with various government regulations, has provided the widest opportunity for banks operating on the principle of profit-sharing/sharia (Antonio, 2001).

As a financial institution, performance appraisal for management is an indicator of the performance achieved by the company. In this case, profit can be used to measure the achievements of a company. Banks need to maintain high profitability. Thus, their performance is considered good. Maintaining high profitability can increase public confidence to save excess funds held in the bank. Good profitability performance is needed for the smooth run of banks as 
intermediary institutions, bank financial statements are the main assessment for bank profitability (Hutagalung et al, 2013).

According to Fernos (2017) profitability requires important attention since for its survival, a bank must be profitable. The high and low profitability of a bank is very influential on the level of public trust. A bank that has a high level of profitability reflects that the bank has a good performance. Profitability can be measured by using Return on Equity (ROE) in general companies and Return on Assets (ROA) in banking firms. Profitability used in Islamic banking is ROA so it can take into account the ability of bank management to obtain overall profits. Hendrawan \& Lestari (2017) state that the assessment of the financial performance of a banking company is one of the most important factors for banking because it is used to see whether the bank is performing well. Financial performance measures can also be used to find out how much profits the bank gets by comparing the results of a certain year's profit with the profit of the previous year and after.

Several factors affecting bank performance are CAR, NPF, and FDR. Capital Adequacy Ratio (CAR) is a financial ratio related to banking capital where the amount of a bank's capital will affect whether a bank can efficiently carry out its activities (Pinasti \& Mustikawati, 2018). NonPerforming Financing (NPF) is a comparison between non-performing loans and loans given to debtors. Financing to Deposit Ratio (FDR) is a ratio used to measure the ability of a bank to pay its debts and repay its depositors and fulfill credit requests submitted. This study was intended to analyze the effect of the capital adequacy ratio, non-performing financing, and financing to deposit ratio on profitability (a case study on Indonesian Islamic commercial banks).

\section{LITERATURE REVIEW AND HYPOTHESIS DEVELOPMENT Profitability}

Profitability is very crucial in a banking firm. The purpose of establishing a bank is definitely to make a profit. Profitability is one of the important things for a business for its survival. Profitability shows whether a business entity has good prospects in the future. Profitability is a business entity's ability to generate profits in a certain determined period (Husnan, 1998). The higher the level of bank profitability reflects that a bank has a good performance. The profitability ratio is a ratio used to assess the ability of a company to seek profit. Profitability ratios consist of ratios that show the profit generated in activities with sales and investments. Profitability can be measured using Return On Equity (ROE) and Return On Assets (ROA) (Husnan, 1998).

\section{Return on Asset (ROA)}

Return on Assets (ROA) in this study was used to calculate the proxies of bank profitability. Return on Assets ( $\mathrm{ROA}$ ) is one of the profitability ratios used to measure the 
company's effectiveness in generating profits by utilizing its total assets. ROA is the ratio between profit before tax to total assets. The greater the ROA indicates the better financial performance since the return is getting bigger. If ROA increases, it means that the company's profitability increases, so the final impact is an increase in profitability enjoyed by shareholders (Husnan, 1998). Based on Bank Indonesia regulations, a good ROA standard is around 1.5\%. The calculation of ROA consists of Calculating Earning Before Tax (EBT) the firm's bank profit before tax and calculating all assets owned by the bank consisting of current assets and fixed assets.

\section{Capital Adequacy Ratio (CAR)}

Capital Adequacy Ratio is a ratio used to measure the ability of banks to maintain sufficient capital and to identify, measure, supervise, and control the risks that arise that can affect the amount of bank capital (Kuncoro \& Suhardjono, 2002). According to Bank Indonesia regulations, the Capital Adequacy Ratio (CAR) has a minimum value of $8 \%$.

Bank capital consists of two components, namely core capital and supplementary capital. Core capital is capital originating from bank owners consisting of paid-up capital by shareholders, reserves, and retained earnings. Meanwhile, supplementary capital consists of fixed asset revaluation reserves, allowance for possible losses on productive assets, loan capital, and subordinated loans. The minimum capital requirement of a bank is calculated based on the RWA (Risk-Weighted Assets) which is the sum of RWA for balance sheet and RWA for administrative assets. RWA for balance sheet assets is obtained by multiplying the nominal value of the assets concerned with the risk weight of each asset. RWA for administrative assets is obtained by multiplying the nominal value of the administrative account concerned with the risk. The higher the CAR, the better the condition of a bank (Achmad dan Kusumo, 2003). If the CAR value is high, it means that the bank can finance the bank's operations; a favorable situation for the bank will make a significant contribution to profitability (Kuncoro \& Suhardjono, 2002).

\section{Non-Performing Financing (NPF)}

Non-Performing Financing (NPF) is a ratio used to measure the ability of bank management to manage non-performing loans provided by banks (Dewi, 2015). The lower the NPF, the more the profits, on the other hand, if the NPF level is high, the bank will experience losses due to the rate of return on bad loans. The increase in Non-Performing Financing (NPF) during the crisis directly affected the decline in liquidity for the banking sector since there was no income either in the form of principal payment or interest from bad loans. If this is allowed, it will affect the loss of public confidence. The current amount of NPF allowed by Bank Indonesia is a maximum of $5 \%$. If it exceeds $5 \%$, it will affect the assessment of the soundness of the bank concerned, which will reduce the score obtained. The higher the NPF level indicates that the bank 
is unprofessional in managing its credit as well as indicating that the risk level for lending to the bank is quite high in line with the high NPF of the bank (Riyadi \& Yulianto, 2014)

\section{Financing to Deposit Ratio (FDR)}

Financing to Deposit Ratio (FDR) is a ratio that shows the bank's ability to provide funds to debtors with the capital owned by the bank as well as funds that can be collected by the public (Kurniasih, 2016a). Financing to Deposit Ratio (FDR) is used to measure the ability of the bank to pay its debts and pay them back to its depositors and meet the loan requests submitted. FDR is the ratio between the total credit given to a third party. The amount of credit disbursed will determine the bank's profit. If the bank cannot channel credit while there are a lot of funds collected, it will cause losses to the bank (Chaplin \& Kasmir, 2004). Bank Indonesia regulations concerning the Financing to Deposit Ratio (FDR) are between 80\% to 110\% (Werdaningtyas, 2002). The higher the Financing to Deposit Ratio (FDR), the bank's profit will increase (assuming the bank can channel its credit effectively). With the increase in bank profit, the bank's performance will also increase. Thus, the size of the Financing to Deposit Ratio (FDR) of a bank will affect the performance of the bank. Good bank performance is expected to increase profitability and public trust.

\section{Hypothesis Development}

\section{Effect of Capital Adequacy Ratio on Profitability}

Capital Adequacy Ratio (CAR) is related to capital in banking. The amount of a bank's capital will affect whether a bank can carry out its activities efficiently. The higher the CAR, the better the condition of a bank. The high CAR value means that the bank can finance the bank's operations, a favorable condition for the bank will make a significant contribution to profitability. High CAR value will greatly affect the level of public trust (Munawir et al., 2019).

$\mathrm{H}_{1:}$ Capital Adequacy Ratio (CAR) has a positive effect on Return on Assets (ROA)

\section{Effect of Non-Performing Financing on Profitability}

Non-Performing Financing (NPF) is used to measure the ability of bank management in managing non-performing loans provided by banks. A bank can be said to have a good NPF if the number of non-performing loans is smaller than the amount of credit granted by the debtor (Dewi, 2015). If a bank has a low NPF, it can reduce costs. The lower the NPF of a bank, the more improved the performance of the bank and the more the increase of the bank's profits.

$\mathrm{H}_{2:}$ Non-Performing Financing (NPF) has a positive effect on Return on Assets (ROA)

\section{Effect of Financing to Deposit Ratio on Profitability}

A company is required to maintain its liquidity and ensure good operations in fulfilling its obligations. The amount of credit disbursed will determine the profits obtained by the bank. If 
there are a lot of funds raised but the bank is unable to distribute them, it will cause losses to the bank. The higher the Financing to Deposit Ratio (FDR), the more the profit obtained by the bank (Kurniasih, 2016). The more the bank profits, the more increased the performance of the bank. The performance of a good bank will increase profits and public confidence.

$\mathrm{H}_{3}$ : Financing to Deposit Ratio (FDR) has a positive effect on Return on Assets (ROA)

Figure 1. Conceptual Framework

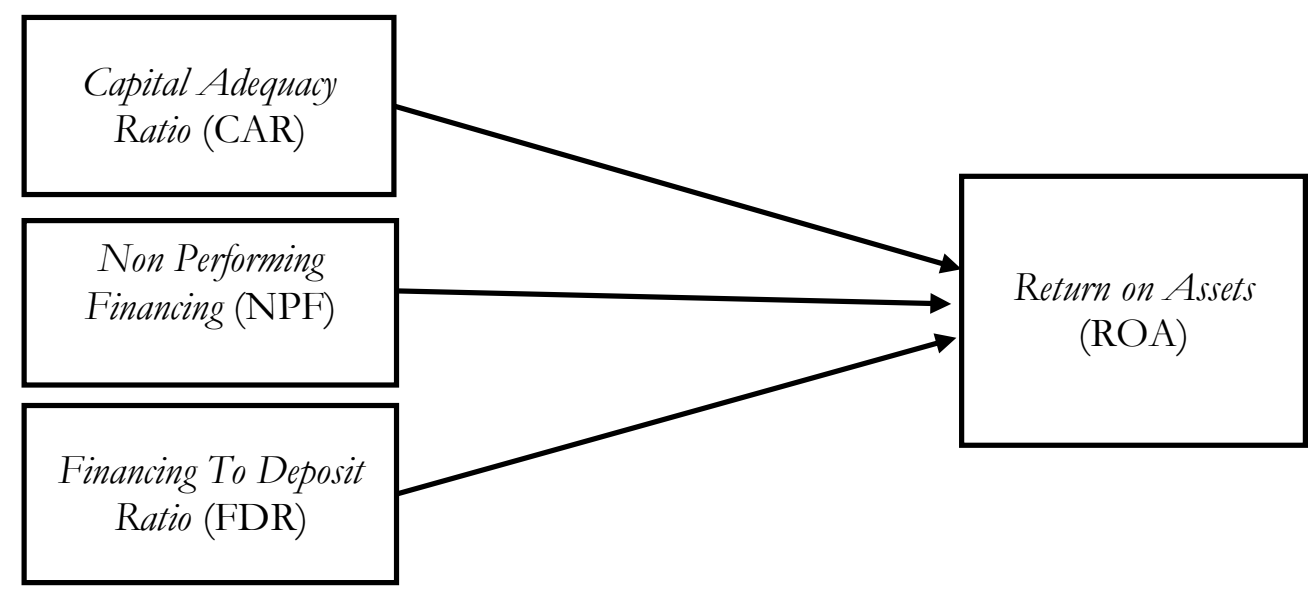

\section{METHOD}

\section{Research Design}

This research employed a quantitative model. A quantitative method is a type of research that has systematic, planned, and clearly structured specifications from the beginning to the end of the research design. A quantitative method is a method with a scientific approach where the research data is in the form of numbers. Its analysis uses statistics. As observed from the type of research, this research is included in the causal-associative research. Causal-associative research aims to analyze the causal relationship or the resulting effect between the independent variable and the dependent variable. This study aims to determine the effect of Capital Adequacy Ratio (CAR), Non-Performing Financing (NPF), and Financing to Deposit Ratio (FDR) on Return on Assets (ROA).

\section{Population and Sample}

The population is a collection of all objects of research. The population in this study is 14 Islamic Commercial Banks listed on the Indonesia Stock Exchange during 2016-2018. The sample is part of the data obtained from the population to be used as a research sample. In this study, the purposive sampling method was used. The purposive sampling technique is used for determining samples with certain considerations of criteria that are assessed according to the objectives or research problems in a population. The sampling criteria are presented in Table 1. 
Table 1. Sampling Criteria

\begin{tabular}{|c|l|c|c|}
\hline No. & \multicolumn{1}{|c|}{ Criteria } & $\begin{array}{c}\text { Does Not Meet } \\
\text { Criteria }\end{array}$ & $\begin{array}{c}\text { Meets } \\
\text { Criteria }\end{array}$ \\
\hline 1 & $\begin{array}{l}\text { Number of Sharia Commercial Bank } \\
\text { Sharia Commercial Bank provide complete } \\
\text { financial reports and publishes them } \\
\text { consistently during 2016-2018. } \\
\text { Sharia Commercial Bank listed on the } \\
\text { Indonesia Stock Exchange has the required } \\
\text { data during 2016-2018. }\end{array}$ & (5) Banks \\
4 & $\begin{array}{l}\text { Sharia Commercial Bank that earns profits } \\
\text { during the study period. }\end{array}$ & (2) & 3 Banks \\
\hline Number of banks used as research samples per year & (1)
\end{tabular}

Source: Secondary Data Processed in 2021

Based on the criteria mentioned in Table 1, from the population listed on the Indonesia Stock Exchange for 2016-2018 through purposive sampling, a sample of 3 banks was obtained. The list of banks sampled in the study is depicted in Table 2.

Table 2. List of Research Samples

\begin{tabular}{|c|l|l|}
\hline No. & \multicolumn{1}{|c|}{ Firm's Code } & \multicolumn{1}{c|}{ Sharia Commercial Bank } \\
\hline 1 & BRIS & Bank Rakyat Indonesia Syariah/Bank Syariah \\
2 & PNBS & Indonesia \\
3 & BTPS & Bank Panin Dubai Syariah \\
\hline
\end{tabular}

Source: www.idx.co.id

\section{Operational Definition and Measurement of Variables}

\section{Capital Adequacy Ratio (CAR)}

CAR is a financial ratio related to the adequacy of bank capital where the amount of capital can affect whether a bank can efficiently carry out its activities. CAR is capital that shows the bank's ability to provide funds for business development purposes and accommodate the risk of loss of funds caused by bank operations (Bilian \& Purwanto, 2017). The greater the CAR, the better the strength of the bank to support the risk of any risky asset loan. If the CAR value is large, the bank can fund the company's operating activities.

The CAR value of the bank can be calculated by the formula:

$$
\text { Capital Adequacy Ratio }=\frac{\text { Eligible Capital }}{\text { Risk-weighted assets }} \times 100 \%
$$




\section{Non-Performing Financing (NPF)}

The most unsatisfactory lending for the bank is when the credit becomes non-performing loans. This was mainly due to the debtor's failure in fulfilling its obligations to pay the principal installments along with the interest agreed by both parties in the credit agreement. According to Kasmir (2010), NPF is a ratio used to assess the risk of distributed loans by combining the total distributed loans with non-performing loans. Management's ability to manage bad loans is the most important part of the activities of banking companies. The formula is:

Non Performing Financing $=\frac{\text { NPF Total }}{\text { Total amount of Financing }} \times 100 \%$

\section{Financing to Deposit Ratio (FDR)}

Financing to Deposit Ratio (FDR) is the ratio between all loans given by the bank and the funds received by the bank. This ratio shows one of the bank's liquidity assessments. The higher the ratio, the lower the liquidity capacity of the bank. Some banking practitioners agree that the safe limit of a bank's FDR is around 80\%. However, the tolerance limit ranges from $85 \%$ to $100 \%$ (Dendawijaya, 2005). The formula is as follows:

Financing to Deposit Ratio $=\frac{\text { Total Amount of Financing }}{\text { Total Deposits }} \times 100 \%$

\section{Profitability}

The dependent variable in this study is Profitability which is measured using the ratio of Return on Assets (ROA). In this study, ROA is used as an indicator of bank performance, which shows the effectiveness of the company in generating profits by optimizing the assets (Dendawijaya, 2009). A ratio that describes the extent to which the company's assets can generate profits. Thus, it can be concluded that the greater the net profit obtained by a company, the better the company's performance. Mathematically, ROA can be formulated as follows:

$$
\text { Return on Asset }=\frac{\text { Operating Income }}{\text { Total Assets }} \times 100 \%
$$

\section{Population and Sample}

The population in this study are people who have watched the "Kalam-Kalam Langit" movie that was released in 2016. The sample of this study is part of the number and characteristics of the population. In this study, the exact population is not known. Thus, in order to determine the sample size of the study from the existing population, the following formula can be used (Suhartanto, 2014).

$$
\mathrm{E}=\mathrm{Z} \frac{\pi_{(1-\pi)}}{n}
$$


Where:

$$
\begin{array}{ll}
\mathrm{N} & =\text { Number of Samples } \\
\mathrm{Z} & =\text { Normal distribution of } 5 \%(1.96) \\
\pi & =\text { Proportion of population } \\
\mathrm{E} & =\text { Maximum margin of error }
\end{array}
$$

The maximum margin of error is the maximum tolerable error rate for sampling at $10 \%$. Using this formula, the sample can be formulated:

$$
\begin{aligned}
\mathrm{E} & =(0.5)(1-0.05) \frac{2_{(1.96)}}{0.1} \\
& =96.04
\end{aligned}
$$

\begin{tabular}{|c|c|c|}
\hline Variable & Definition & Indicator \\
\hline \multirow{4}{*}{$\begin{array}{l}\text { Elements in the } \\
\text { Movie } \\
\text { (Seongseop Sam } \\
\text { Kim \& Kim, } \\
\text { 2017) }\end{array}$} & \multirow{4}{*}{$\begin{array}{l}\text { The elements felt by the audience } \\
\text { after seeing or watching a movie } \\
\text { consisting of narrative and } \\
\text { cinematographic (Kim \& Kim, } \\
\text { 2017) }\end{array}$} & Actor/actress \\
\hline & & Message conveyed \\
\hline & & $\begin{array}{l}\text { The scenery/ background of } \\
\text { the story }\end{array}$ \\
\hline & & Plot \\
\hline \multirow{4}{*}{$\begin{array}{l}\text { Affective Image } \\
\text { (Soojin Lee, } \\
\text { Scott, \& Kim, } \\
2008 \text { ) }\end{array}$} & \multirow{4}{*}{$\begin{array}{l}\text { Affective image refers to a } \\
\text { person's feelings about a specific } \\
\text { tourism destination (Lee, Scott, \& } \\
\text { Kim, 2008). }\end{array}$} & No fun $><$ Fun \\
\hline & & Boring $><$ Rousing \\
\hline & & Gloomy $><$ Interesting \\
\hline & & Sad $><$ Relaxed \\
\hline \multirow{4}{*}{$\begin{array}{l}\text { Cognitive Image } \\
\text { (Artuger, } \\
\text { Cestinoz, \& } \\
\text { Kihc, 2013) }\end{array}$} & \multirow{4}{*}{$\begin{array}{l}\text { Cognitive images show belief or } \\
\text { knowledge about the attributes of } \\
\text { a destination. Individual } \\
\text { perceptions are formed from } \\
\text { several images that are accepted as } \\
\text { internal attributes (Artuger et al., } \\
\text { 2013) }\end{array}$} & Nature tourism \\
\hline & & Public infrastructure \\
\hline & & Atmosphere \\
\hline & & Value for money \\
\hline \multirow{3}{*}{$\begin{array}{l}\text { Halal Travel } \\
\text { Intentions } \\
\text { (Seongseop Sam } \\
\text { Kim \& Kim, } \\
\text { 2017) }\end{array}$} & \multirow{3}{*}{$\begin{array}{l}\text { Travel intention is a consumer } \\
\text { behavior that shows the extent of } \\
\text { their commitment to travel (Kim } \\
\text { \& Kim, 2017) }\end{array}$} & Visit interest \\
\hline & & Travel motivation \\
\hline & & Intention for word of mouth \\
\hline
\end{tabular}

From the calculation, the sample number was 96.04 and was rounded off to 100 respondents.

\section{Operational Definition of Variables}

Table 1 is the indicators of each variable used in this study:

Table 1. Operational Definition of Variables

\section{RESULTS}




\section{Descriptive Statistical Analysis}

Descriptive statistical analysis is used to describe and explain the variables (CAR, NPF, and FDR) which can be seen from the maximum value, minimum value, mean, and standard deviation.

Table 3. Results of Descriptive Statistical Analysis

\begin{tabular}{|l|c|c|c|c|c|}
\hline & N & Minimum & Maximum & Mean & $\begin{array}{c}\text { Std. } \\
\text { Deviation }\end{array}$ \\
\hline CAR & 18 & 10.05 & 40.90 & 20.0378 & 7.84623 \\
NPF & 18 & 1.39 & 12.52 & 4.6389 & 2.92362 \\
FDR & 18 & 71.87 & 95.60 & 86.9928 & 6.74514 \\
ROA & 18 & -10.77 & 12.40 & 2.2333 & 5.08049 \\
\hline Valid N & 18 & & & & \\
(listwise) & & & & & \\
\hline
\end{tabular}

Source: Secondary Data Processed in 2021

Table 3 shows the results of the descriptive statistical analysis. The number of samples $(\mathrm{N})$ is 18. The variable of Capital Adequacy Ratio (CAR) has a minimum value of 10.05 and a maximum value of 40.90 . The mean is 20.0378 . The standard deviation is 7.84623 . The mean is greater than the standard deviation so that the distribution of CAR data is good. The Non-Performing Financing (NPF) has a minimum value of 1.39 and a maximum value of 12.52 . The variable of the average value (mean) is 4.6389 with a standard deviation of 2.92362 , which means that the mean value is greater than the standard deviation so that the distribution of NPF data is good. The variable of Financing to Deposit Ratio (FDR) has a minimum value of 71.87 and a maximum value of 95.60. The mean is 86.9928 with a standard deviation of 6.74514 , which means that the mean value is greater than the standard deviation so that the FDR data distribution is good. The Return on Asset (ROA) has a minimum value of -10.77 and a maximum value of 12.40 . The variable of the average value (mean) is 2.2333 with a standard deviation of 5.08049 , which means that the mean value is smaller than the standard deviation so that the ROA data distribution is not good.

\section{Classical Assumption Test}

The normal distribution indicates that the regression model is good. Thus, it can be analyzed further. In this study, to determine whether the residual data is normally distributed, the Kolmogorov-Smirnov Test (K-S) was used. The results of the normality test obtained the Asymp value. Sig. (2-tailed) of 0.527 . The value is greater than 0.05 or $(0.527>0.05)$. Thus, it can be concluded that the data is normally distributed.

Multicollinearity test was used to test whether the regression model found a correlation between independent variables. In a good regression model, there should be no multicollinearity. Multicollinearity test results show that the variable of Capital Adequacy Ratio (CAR) has a tolerance of $0.588>0.10$ and a VIF of $1.791<0.10$. Thus, the variable of CAR is declared to have 
no multicollinearity. The variable of Non-Performing Financing (NPF) has a tolerance of $0.566>$ 0.10 and a VIF of $1.768<0.10$. Thus, the variable of NPF is declared to have no multicollinearity. The variable of Financing to Deposit Ratio (FDR) has a tolerance of $0.726>0.10$ and a VIF of $1.378<0.10$. Thus, the variable of FDR is declared to have no multicollinearity.

The autocorrelation test aims to test whether in the linear regression model there is a problem of correlation of observations between different periods. The autocorrelation test can be done using the Durbin-Watson (DW) test. In order to determine whether the regression model has autocorrelation or not, it can be seen from the size of the value between 2.5 to 4.0. Thus, it has a negative autocorrelation. The results of the autocorrelation test showed 3.072. since the Durbin-Watson oft $>2.5$ and $<4.0$, in this study, there was a negative problem of autocorrelation.

The heteroscedasticity test is to test whether in the regression model there is a variable inequality from the residual observations with another observation in the previous period. The results of the Heteroscedasticity Test using the Glejser Test show that the significance value (sig) for the variable of CAR is 0.051 , the significance value (sig) for the variable of NPF is 0.027 , the significance value (sig) for the variable od FDR is 0.585 . The significance value of the variables od CAR and FDR show results of $>0.05$. Thus, there is no heteroscedasticity. Meanwhile, the variable of NPF showed results $<0.05$. Thus, heteroscedasticity occurs.

\section{Data Analysis}

The data analysis in this study used multiple linear regression to analyze the effect of the independent variables (CAR, NPF, and FDR) on the dependent variable of Profitability (ROA) of Islamic Commercial Banks in Indonesia listed on the Indonesia Stock Exchange in 2016-2018. The results of the multiple linear regression analysis can be seen in Table 4 .

Table 4. Multiple Linear Regression Test Results

\begin{tabular}{lccccl}
\hline \multicolumn{1}{c}{ T test } & $\mathbf{B}$ & $\mathbf{T}_{\text {count }}$ & $\mathbf{t}_{\text {table }}$ & Sig. & Description \\
\hline (Constant) & 2.744 & & & & \\
CAR & 0.257 & 1.791 & 1.34061 & $.095^{* * *}$ & Accepted \\
NPF & -.845 & -2.208 & 1.75305 & $.044^{* *}$ & Accepted \\
& & & & & \\
FDR & -.020 & -0.027 & 1.34061 & .893 & Rejected \\
& & & & & \\
\hline Uji Statistik F & & 7,488 & & \\
\hline Nilai F & & $.003^{\mathrm{b}}$ & & \\
Sig. & & & & \\
& & & & & \\
\hline Uji Koefisien & & & & \\
Determinasi & & & & & \\
\hline
\end{tabular}


R Square

Adjusted R

Square
.616

.534

Description $*$ significance $1 \%,{ }^{* *}$ significance $5 \%,{ }^{* * *}$ significance $10 \%$

\section{DISCUSSION}

\section{Effect of Capital Adequacy Ratio (CAR) on Profitability}

Capital Adequacy Ratio (CAR) is a ratio related to the capital adequacy of a banking company where the amount of capital can affect whether a bank can efficiently carry out its operational activities. Based on the results of the t-test, the Capital Adequacy Ratio (CAR) variable has a regression coefficient value of 1.791 where this value indicates a positive direction with a significance level of 0.095. It is greater than 0.05. It can be concluded that the Capital Adequacy Ratio (CAR) has a positive and no significant effect on the profitability of Islamic commercial banks in Indonesia.

This is possible because since after setting the provisions of the Capital Adequacy Ratio (CAR) ratio of at least $8 \%$, bank owners must increase bank capital by providing funds so that the Capital Adequacy Ratio (CAR) can meet the requirements set by Bank Indonesia. It does not try to make the capital provide a significant influence on the profitability of the bank. Another possibility is that banks do not use the full potential of capital to increase bank profitability, in other words, a lot of funds must be accommodated without being channeled to third parties.

In this case, the bank prioritizes public trust. Thus, as long as the public believes in the bank's performance, the bank capital that has been required at $8 \%$ will not affect the bank's performance. The results of this study are in line with research that has been carried out by (Agustiningrum, 2013), (Idris \& Sa'diah, 2020), (Santosa et al., 2020), (Susan Rachmawati 1, 2019), (Pinasti \& Mustikawati, 2018), (Risky Diba Avrita 1, 2016) that the Capital Adequacy Ratio (CAR) has a positive and no significant effect on the Return Adequacy Ratio (ROA).

\section{Effect of Non-Performing Financing (NPF) on Profitability}

Non-Performing Financing (NPF) is the ratio between total non-performing loans and total loans given to debtors. This ratio shows the ability of bank management in managing nonperforming loans. Based on the t-test results, the variable of Non-Performing Financing (NPF) has a regression coefficient value of -2.208 where this value indicates a negative direction with a significant level of 0.044 which means it is smaller than 0.05 . It can be concluded that NonPerforming Financing (NPF) has a negative and significant effect on the Return Adequacy Ratio (ROA). 
Thus, the lower the NPF, the lower the risk that must be borne by the bank. Banks can control the number of non-performing loans so that the number of loans extended to debtors is greater. The lower the NPF value of a bank, the more improved the bank's operational performance. The low non-performing loans will facilitate the income that can be received by the bank. Thus, it can increase the profitability of a bank. The results of this study are in line with the results of previous researches (Agustiningrum, 2013); (Rahmi \& Sari, 2019); (Idris \& Sa'diah, 2020); (Santosa et al., 2020); and (Risky Diba Avrita 1, 2016) that Non-Performing Financing (NPF) has a negative and significant effect on the Return Adequacy Ratio (ROA).

\section{Effect of Financing to Deposit Ratio (FDR) on Profitability}

Financing to Deposit Ratio (FDR) is a ratio used to measure a bank's ability to repay withdrawals made by depositors by relying on loans provided as a source of liquidity. FDR is a comparison ratio between the total credit given to third-party funds. Based on the t test results, the variable of Financing to Deposit Ratio (FDR) has a regression coefficient value of -0.137 where this value indicates a negative direction with a significance level of 0.893 which means it is greater than 0.05. It can be concluded that the Financing to Deposit Ratio (FDR) has a negative and insignificant effect on profitability.

Hence, the higher the FDR value, the more increased the bank's profit with the assumption that the bank can channel its credit effectively. With the increase in bank profit, the bank's performance will also increase. Thus, good bank performance is expected to increase profitability and public trust. The results of this study are not in line with previous researches (Agustiningrum, 2013); (Idris \& Sa'diah, 2020); (Santosa et al., 2020) and (Bilian \& Purwanto, 2014) that the Financing To Deposit Ratio (FDR) has a positive and significant effect on the Return Adequacy Ratio (ROA).

\section{CONCLUSION AND SUGGESTION}

This study examined the effect of Capital Adequacy Ratio (CAR), Non-Performing Financing (NPF), and Financing to Deposit Ratio (FDR) on the Profitability of Islamic Commercial Banks. The conclusion of this study is that the variable of Capital Adequacy Ratio (CAR) has a positive and significant effect on profitability. Thus, the first hypothesis $\left(\mathrm{H}_{1}\right)$ which states that the Capital Adequacy Ratio (CAR) has a positive and significant effect on the profitability of Islamic commercial banks in Indonesia is accepted. The variable of NonPerforming Financing (NPF) has a negative and significant effect on the profitability of Islamic commercial banks in Indonesia. Thus, the second hypothesis $\left(\mathrm{H}_{2}\right)$ which states that NonPerforming Financing (NPF) has a significant effect on the profitability of Islamic commercial 
banks in Indonesia is proven true but has the opposite/negative direction. The variable of Financing to Deposit Ratio (FDR) has a negative and insignificant effect on the profitability of Islamic commercial banks in Indonesia. Thus, the third hypothesis $\left(\mathrm{H}_{3}\right)$ which states that the Financing to Deposit Ratio (FDR) has a positive and significant effect on the profitability of Islamic commercial banks in Indonesia is not proven true.

The limitations of this study are expected to provide an overview and opportunities for future researchers to conduct better research. The limitations of this study include (1) the sample of only 6 Islamic banking firms listed on the Indonesia Stock Exchange, (2) the use of only three independent variables of Capital Adequacy Ratio (CAR), Non-Performing Financing (NPF), Financing to Deposit Ratio (FDR) in influencing the profitability of Islamic commercial banks in Indonesia, (3) the profitability assessment of only Return on Assets (ROA), and (4) the research period in the span of 3 years of 2016-2018.

Further researchers are expected to be able to add more independent variables outside of the variables in this study to obtain more diverse results on things that can affect the profitability of Islamic commercial banks and use profitability assessments other than Return on Assets (ROA). It is suggested to add years of observation by choosing a sample that is representative in explaining profitability in Islamic Commercial Banks. Islamic Commercial Banks are expected to maintain the ratio of Capital Adequacy Ratio (CAR), Non-Performing Financing (NPF), and Financing to Deposit Ratio (FDR) with the regulation set by Bank Indonesia to control the bank's performance to increase bank profitability. This research is also expected to be used as consideration for banking firms in evaluating the soundness of banks and maintaining the stability of the bank's financial system regarding the amount of use of own capital in bank operations, management of nonperforming loans, the efficiency of operations, and distribution of third-party funds to increase the bank's profit or to do further evaluation.

\section{REFERENCES}

Achmad, T., \& Kusumo, W. K. (2003). Analisis Rasio Keuangan Sebagai Indikator Dalam Memproteksi Potensi Kondisi Bermasalah Perbankan di Indonesia. Media Ekonomi Dan Bisnis, 15(1).

Agustiningrum, R. (2013). Analisis pengaruh capital adequacy ratio, non performing loan dan loan to deposit ratio terhadap profitabilitas pada perusahaan perbankan. Jurnal Universitas Udayana, 885-902.

Ali, K., Akhtar, M. F., \& Ahmed, H. Z. (2011). Bank-specific and macroeconomic indicators of profitability-empirical evidence from the commercial banks of Pakistan. International Journal of Business and Social Science, 2(6), 235-242. 
Antonio, M. S. (2001). Bank Syariah: Dari Teori ke Praktik., Jakarta. Gema Insani Press. Hal, 4, 37.

Avrita, R. D., \& Pangestuti, I. R. D. (2016). Profitabilitas Bank (Perbandingan Bank Umum Go Public Dan Bank Umum Non Go Public Di Indonesia Periode Tahun 2011-2014 ). 5, 1-13.

Bilian, F., \& Purwanto, P. (2014). Analisis Pengaruh CAR, NIM, BOPO, dan LDR Terhadap Profitabilitas Bank Persero 1 2. FIRM: Journal of Management Studies, 2(1), 155-168.

Bilian, F., \& Purwanto, P. (2017). Pengaruh Ratio-ratio Keuangan Car, LDR, NIM, BOPO, NPL Terhadap ROA. FIRM: Journal of Management Studies, 2(1), 155-168.

Chaplik, N., \& Kasmir, S. P. (2004). Method and system for combining symmetric DSL signals and voice signals. Google Patents.

Dendawijaya, L. (2005). Manajemen perbankan. Jakarta: Ghalia Indonesia.

Dendawijaya, L. (2009). Manajemen Perbankan: Edisi Revisi Ciawi Bogor. Ghalia Indonesia.

Dewi, L. E. (2015). dkk. 2015.“Analisis Pengaruh NIM, BOPO, LDR, dan NPL Terhadap Profitabilitas (Studi Kasus Pada Bank Umum Swasta Nasional Yang Terdaftar Pada Bursa Efek Indonesia Periode 2009-2013).” E-Jurnal S1 Ak. Universitas Pendidikan Ganesha, 3(1).

Fernos, J. (2017). Analisis Rasio Profitabilitas Untuk Mengukur Kinerja (Studi Kasus Pada PT. Bank Pembangunan Daerah Provinsi Sumatera Barat). Jurnal Pundi, 1(2), 107-118.

Hendrawan, Y. P., \& Lestari, H. S. (2017). Faktor-Faktor Penentu Profitabilitas Bank Umum yang Terdaftar Di Bursa Efek Indonesia (BEI). Jurnal Manajemen Dan Pemasaran Jasa, 9(1), 99-118.

Husnan, S. (1998). Manajemen keuangan teori dan penerapan. Yogyakarta: BPFE Yogyakarta.

Hutagalung, B., Dalimunthe, D. M., Pambudi, R., Hutagalung, A. Q., \& Muda, I. (2017). The effect of enterpreneurship education and family environment towards students' entrepreneurial motivation. International Journal of Economic Research, 14(20), 331-348.

Idris, A. S., \& Sa'diah. (2020). Metode Camel dalam Pengukuran Profitabilitas Perusahaan Perbankan yang Terdaftar di Bursa Efek Indonesia (BEI) Periode 2016 - 2018. Jurnal Ekonomi, 22(1), 87-101.

Kasmir, B., \& Lainnya, L. K. (2010). Jakarta: PT. RajaGrafindo Persada.

Kuncoro, M., \& Suhardjono. (2002). Manajemen Perbankan Teori dan Aplikasi (Vol. 1). BPFE Yogyakarta.

Kurniasih, E. (2016a). Pengaruh Capital Adequacy Ratio, Non Performing Loan, Loan To Deposit Ratio, Efisiensi Operasi, Not Interest Margin Terhadap Return On Aset (Studi Empiris pada Perusahaan Perbankan yang Listing di BEI tahun 2009-2014). Journal Of Accounting, 2(2).

Kurniasih, E. (2016b). Pengaruh CAR, NPL, LDR, Efisiensi Operasi, NIM Terhadap ROA Pada Bank yang Listing di BEI. Journal Of Accunting, 2, 1-14.

Masood, O., \& Ashraf, M. (2012). Bank-specific and macroeconomic profitability determinants of Islamic banks. Qualitative Research in Financial Markets. 
Munawir, Nurnajamuddin, M., \& Suryanti. (2019). Pengaruh Struktur modal dan pertumbuhan perusahaan terhadap profitabilitas. Center Of Economic Student Journal, 2(2), 1-12.

Pinasti, W. F., \& Mustikawati, R. R. I. (2018). Pengaruh CAR, BOPO, NPL, NIM Dan LDR Terhadap Profitabilitas Bank Umum Periode 2011-2015. Nominal, Barometer Riset Akuntansi Dan Manajemen, 7(1), 126-142.

Rachmawati, S., \& Marwansyah, S. (2019). Pengaruh Inflasi, BI Rate, Car, NPL, Bopo Terhadap Profitabilitas Pada Bank BUMN. Jurnal Mantik, 3(1), 117-122.

Rahmi, M., \& Sari, R. (2019). Risk-Based Bank Ratio on Profitability of Sharia Banking. Econosains, $8(5), 1-13$.

Riyadi, S., \& Yulianto, A. (2014). Pengaruh Pembiayaan bagi Hasil, Pembiayaan Jual Beli, Financing to Deposit Ratio (FDR) dan Non Performing Financing (NPF) terhadap Profitabilitas Bank Umum Syariah di Indonesia. Accounting Analysis Journal, 3(4).

Santosa, M. E. S., Pradnyana, I. P. R., \& Putra, I. G. C. (2020). Determinant of Financial Performance on Banking Listed Indonesian Stock Exchange 2013-2018. International Journal of Sustainability, Education, And Global Creative Economic (IJSEGCE), 3(3), 583-592.

Werdaningtyas, H. (2002). Faktor yang Mempengaruhi Profitabilitas Bank Take Over Pramerger di Indonesia. Jurnal Manajemen Indonesia, 1(2), 24-39.

Yuliarti, N. C. (2014). Pengaruh kecukupan modal, risiko pembiayaan, efisiensi operasional, dan fungsi intermediasi terhadap profitabilitas pada perbankan syariah di indonesia. Jurnal Ilmiah Progresif, 11, 28. 